\title{
Risk of Recrudescence of Lymphatic Filariasis after Post-MDA Surveillance in Brugia malayi Endemic Belitung District, Indonesia
}

\author{
Santoso ${ }^{1, *, \dagger} \mathbb{D}$, Yahya ${ }^{1, \dagger}$, Yanelza Supranelfy ${ }^{1, \dagger}$, Nungki Hapsari Suryaningtyas ${ }^{1, \dagger}$, Yulian Taviv ${ }^{1}$, Aprioza Yenni', \\ Maya Arisanti', Rika Mayasari', Vivin Mahdalena', Rizki Nurmaliani', Marini', K. Krishnamoorthy², \\ Helena Ullyartha Pangaribuan ${ }^{3}$ (D) \\ ${ }^{1}$ Baturaja Unit for Health Research and Development, National Institute of Health Research and Development (NIHRD), Ministry of Health of \\ Indonesia, South Sumatera, Indonesia; ' Vector Control Research Centre (VCRC), Medical Complex, Indira Nagar, Puducherry, India; \\ ${ }^{3}$ National Institute of Health Research and Development, Ministry of Health, Jakarta, Indonesia
}

\begin{abstract}
Belitung district in Bangka-Belitung Province, Indonesia with a population of 0.27 million is endemic for Brugia malayi and 5 rounds of mass drug administration (MDA) were completed by 2010. Based on the results of 3 transmission assessment surveys (TAS), the district is declared as achieving elimination of lymphatic filariasis (LF) in 2017. The findings of an independent survey conducted by the National Institute of Health Research and Development (NIHRD) in the same year showed microfilaria (Mf) prevalence of 1.3\% in this district. In 2019, NIHRD conducted microfilaria survey in 2 villages in Belitung district. Screening of 311 and 360 individuals in Lasar and Suak Gual villages showed Mf prevalence of $5.1 \%$ and $2.2 \%$ with mean Mf density of 120 and $354 \mathrm{mf} / \mathrm{ml}$ in the respective villages. Mf prevalence was significantly higher among farmers and fishermen compared to others and the gender specific difference was not significant. The results of a questionnaire based interview showed that $62.4 \%$ of the respondents reported to have participated in MDA in Lasar while it was $57.7 \%$ in Suak Gual village. About $42 \%$ of the Mf positive cases did not participate in MDA. Environmental surveys identified many swampy areas supporting the breeding of Mansonia vector species. Persistence of infection is evident and in the event of successful TAS3 it is necessary to monitor the situation and plan for focal MDA. Appropriate surveillance strategies including xenomonitoring in post-MDA situations need to be developed to prevent resurgence of infection. Possible role of animal reservoirs is discussed.
\end{abstract}

Key words: Brugia malayi, Mansonia, lymphatic filariasis, TAS

\section{INTRODUCTION}

Lymphatic filariasis (LF), commonly known as elephantiasis is a parasitic mosquito-borne disease. Global programme to eliminate lymphatic filariasis (GPELF) with mass drug administration (MDA) as the principal strategy and launched in 2000 has made significant progress. By 2018, over 910 million people in the endemic countries were provided treatment using about 7 billion treatments and the World Health Organization (WHO) has validated that 14 countries have have achieved elimination of LF as a public health problem. MDA has been discontinued in another 10 countries and are under

- Received 14 October 2020, revised 1 December 2020, accepted 1 December 2020.

*Corresponding author (santosobaturaja@gmail.com)

†These authors contributed equally to this work.

(c) 2020, Korean Society for Parasitology and Tropical Medicine

This is an Open Access article distributed under the terms of the Creative Commons Attribution Non-Commercial License (https://creativecommons.org/licenses/by-nc/4.0) which permits unrestricted non-commercial use, distribution, and reproduction in any

medium, provided the original work is properly cited.
post-MDA surveillance. MDA is required to cover about 893 million people living in 49 countries to achieve elimination target [1]. About $70 \%$ of the infected population have been reported to live in India, Indonesia, Nigeria and Bangladesh [2].

Lymphatic filariasis is endemic in Indonesia and become a serious public health problem. All the 3 human filarial parasites viz., Wuchereria bancrofti, Brugia malayi and Brugia timori are prevalent in Indonesia. LF is prevalent in 236 out of 514 districts with an estimated population of 102 million people at risk of infection. Being the world's largest island nation with about 5,000 to 6,000 inhabited islands implementation of public health care programmes is a big challenge. Filariasis elimination program was launched in 2003 and achieved cent percent geographical coverage in 2017. Since 2005, MDA was conducted with district as an implementation unit (IU). Monitoring and evaluation of LF elimination programme using the WHO recommended TAS protocol [3] showed that in 2019, 30 IUs have achieved elimination of LF as a public health 
problem, no longer requiring MDA. MDA was conducted in 118 high-risk districts in 2019, targeting 40.7 million people [4] and the remaining districts are under post MDA surveillance. Belitung district, one of the endemic districts stopped MDA in 2010 after 5 annual rounds of MDA since 2006, based on successful TAS1 and based on the successful results of TAS2 and 3, the Ministry of Health, Government of Indonesia declared that this district achieved elimination of LF as a public health problem in 2017. The National Institute of Health Research and Development conducted filariasis survey in selected district including Belitung to support the elimination program. Mf prevalence was 1.3\% [5]. The present study was undertaken to assess the current status of LF infection in Belitung, 10 years after stopping MDA. Sociological survey was also carried out to assess community knowledge and practice of morbidity management of disability prevention (MMDP) during post MDA elimination period.

\section{MATERIALS AND METHODS}

\section{Ethical statement}

This study protocol was reviewed and approved by the Human Ethics Commitee of National Institute of Health Research and Development, Ministry of Health, Republic of Indonesia (No. LB.02.01/2/KE.318/2018; dated 23 November 2018).

\section{Study area}

Belitung is an archipelago district consisting of 98 large and small islands, with a population ranging from 6,300 to
172,000 . The study was conducted in 2 randomly selected villages. Suak Gual village situated in a small island, Mendanau Island. The population of this island (2016) is 4,232 individuals in 1,234 households. (Fig. 1), located about $50 \mathrm{kms}$ from the District capital. Lasar village in Membalong Sub-district, one of the sub-districts located in the main island. The population of Lasar is 3,278 living in 944 houses [6]. The study was conducted from April-November 2019, 2 years after the third TAS and 10 years stopping MDA. Patients with filarial lymphedema were reported in both the villages.

\section{Sampling of study participants}

A cross sectional night blood survey was conducted in the selected villages for detection of filarial infection with Mf. The sample size for $\mathrm{Mf}$ was estimated using a single proportion formula [7]: $N=P(1-p) Z 2 / d 2$, where $P=0.28$ refers to the multicenter filariasis study [8] Z=level of confidence, 1.96 and $\mathrm{d}=5 \%$ marginal error, marginal error, with a minimum sample size of 310 individuals from each study village. The inclusion criteria for the survey were all the individuals above 5 years of age of both the genders and residing in the village for more than 1 year. Informed consent was obtained from the participating individuals. Consent from parents was obtained for the children below 18 years of age.

\section{Parasitologic survey}

Night blood samples were collected from the consenting individuals between 8 PM and 12 PM. Prior to the survey, the survey team visited the village and discussed with the commu-

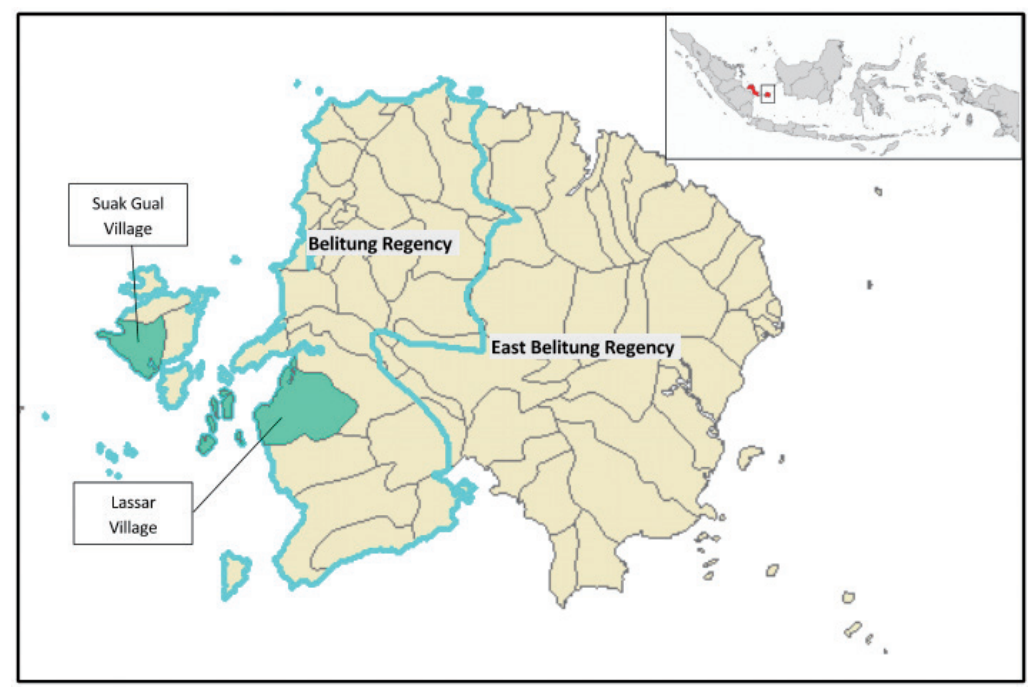

Fig. 1. A map showing study areas, Lasar and Suak Gual villages. 
nity leaders for effective participation of the community in the blood survey. The survey was conducted in the village meeting hall, health care facilities, or places where people can easily reach. Reporting individuals and their family members were screened in the pre-identified sites for the survey. Finger-prick blood sample measuring $60 \mu \mathrm{l}$ was collected from the consenting individuals using disposable lancets and micropipette. Three parallel thick smears each with approximately $20 \mu \mathrm{l}$ blood sample, as per the national guideline [9].

The slides were air dried on a drying rack for 24-72 hr. The air-dried slides were processed for staining and microscopic examination in the laboratory. Blood smears were dehaemoglobinized in tap water for $5 \mathrm{~min}$, left air-dried, fixed in methanol for 3-5 min, stained with Giemsa 3\% for 45 min using straining racks and wash the smear by dipping in in buffered water of distilled water for 3-5 min. Stained slides were examined under a compound microscope use $\times 10$ objective to detect microfilariae presence. Higher magnifications $\times 40$ and $\times 100$ objective [10].

\section{Knowledge and perception study}

A pre-tested semi-structured questionnaire was used to collect information on community awareness and practice on MDA and MMDP. This survey was conducted by trained technical staff prior to blood testing. The survey team visited randomly selected households and one consenting family member aged over 17 years were interviewed in the local language. The questions included on the cause of LF, clinical consequences of LF infection, awareness on MDA and, adverse event (AE) experience in any during MDA.

\section{Environmental survey}

Environmental surveys were conducted by observing the village environment in which the inhabitant lives to identify the potential for mosquito breeding habitat. Mansonia spp. are the main vectors that are peculiar to the fact that its larvae grow along with certain species of floating, unpolluted freshwater plants $[11,12]$.

\section{Statistical analysis}

Data gathered were entered and codified in Excel (version 2010) and analysed in SPSS Ver.17 software (SPSS Inc., Chicago, Illinois, USA). The difference in prevalence was tested for significance using chi-square test. Analysis of risk factor such as gender, occupation and history of participation in MDA was done using bivariate analysis.

\section{RESULTS}

A total of 671 people living in Suak Gual in Mendanau Island and Lasar in the mainland participated in the Mf survey. Out of the total sample, females consisted 54\% (362) while the remaining (309; 46\%) were males. In both the villages, more females participated than males (Table 1). Mean age of participants was 33 years and 39 years in Suak Gual and Lasar respectively. Relatively more individuals in the age class 10-20 yeas participated in the survey. Over $25 \%$ of the participants belong to either students or housewives, followed by farmers and fishermen

A total of $24 \mathrm{Mf}$ positive cases were detected in both the study villages. Microfilaria was identified to Brugia malayi, with conspicuous caudal nuclei (Fig. 2). All positive cases had only B. malayi infection. Mf prevalence was $5.15 \%$ in Lasar while it was $2.2 \%$ in Suak Gual. Mf prevalence was significantly $\left(\chi^{2}=4.13 ; P=0.04\right)$ higher in the village located in the main island compared to the village in small island. Mf prevalence was higher among males (4.6\%) compared to females (2.7\%). However, the difference was not significant (Table 2). The youngest age with Mf infection was 12 years. The proportion of children representing school age of elementary (6-11 years), middle (12-14 years) and high school (15-18 years) were $8.5 \%, 9.4 \%$, and $12.4 \%$ respectively. While no child in the elementary school-age was positive for Mf, Mf prevalence was $0.15 \%$ in middle school age and none in high school-age children respectively. The mean age of Mf positive was 35 years. About $92 \%$ of the positive cases were in the age class above 21 years. Microfilaria count ranged from 1 to 67 per $60 \mu \mathrm{l}$ of blood. The mean of Mf count (MMC) was 120 in Lasar and 354 in Suak Gual with an overall MMC of 198 per $60 \mu$ of blood.

Individuals with Mf-positive by occupations were farmers of $33 \%$, fishermen of $25 \%$, housewives of $17 \%$, and others of $25 \%$. As the farmers and fishermen were the major occupational group, the Mf prevalence in this group was compared with the rest. The Mf prevalence among farmers and fishermen was $6.7 \%$ which was significantly higher than $2.2 \%$ among others. Mf prevalence was comparable between those who reported to have participated in MDA programme (Table 2).

Table 2 shows Mf prevalence in relation to gender, occupation and history of participation in MDA Awareness and par- 
Table 1. Demographic features of population screened in Suak Gual and Lasar villages

\begin{tabular}{|c|c|c|c|c|}
\hline \multirow{2}{*}{ Characteristics } & \multicolumn{2}{|l|}{ Suak Gual } & \multicolumn{2}{|l|}{ Lasar } \\
\hline & Villagers screened $(n=360)$ & Mf positive (\%) & Villagers screened $(n=311)$ & Mf positive (\%) \\
\hline \multicolumn{5}{|l|}{ Sex } \\
\hline Male & 161 & 1.9 & 146 & 7.5 \\
\hline Female & 199 & 2.5 & 165 & 3.0 \\
\hline \multicolumn{5}{|l|}{ Age group } \\
\hline $5-10$ & 36 & 0.0 & 27 & 0.0 \\
\hline $11-15$ & 45 & 2.2 & 38 & 0.0 \\
\hline $16-20$ & 30 & 0.0 & 33 & 0.0 \\
\hline $21-25$ & 18 & 0.0 & 23 & 8.7 \\
\hline $26-30$ & 15 & 0.0 & 22 & 4.5 \\
\hline $31-35$ & 42 & 2.4 & 35 & 2.9 \\
\hline $36-40$ & 37 & 0.0 & 27 & 7.4 \\
\hline $41-45$ & 25 & 4.0 & 22 & 9.1 \\
\hline $46-50$ & 27 & 0.0 & 18 & 22.2 \\
\hline $51-55$ & 25 & 8.0 & 16 & 12.5 \\
\hline $56-60$ & 30 & 10.0 & 19 & 5.3 \\
\hline$>60$ & 30 & 0.0 & 31 & 3.2 \\
\hline \multicolumn{5}{|l|}{ Occupation } \\
\hline Unemployed & 15 & 6.7 & 23 & 4.3 \\
\hline Student & 104 & 1.0 & 78 & 0.0 \\
\hline Housewife & 98 & 1.0 & 86 & 3.5 \\
\hline Government officer/Army/Police & 3 & 0.0 & 2 & 0.0 \\
\hline Government employees & 0 & 0.0 & 1 & 0.0 \\
\hline Employees in private sector & 0 & 0.0 & 3 & 33.3 \\
\hline Entrepreneur & 1 & 7.0 & 12 & 8.3 \\
\hline Service work & 1 & 0.0 & 1 & 0.0 \\
\hline Farmer & 82 & 3.7 & 34 & 14.7 \\
\hline Casual Labourer & 3 & 0.0 & 5 & 0.0 \\
\hline Fisherman & 33 & 3.0 & 52 & 9.6 \\
\hline Others & 8 & 0.0 & 14 & 0.0 \\
\hline
\end{tabular}

Table 2. Microfilaria prevalence in relation to occupation, gender and participation in MDA

\begin{tabular}{lccccc}
\hline Variables & $\begin{array}{c}\text { No. } \\
\text { examined }\end{array}$ & $\begin{array}{c}\text { Mf positive } \\
(\%)\end{array}$ & $P$-value & OR & $95 \% \mathrm{Cl}$ \\
\hline Gender & & & 0.208 & 1.691 & $0.740-$ \\
& & & & & 3.864 \\
Male & 307 & 4.6 & & & \\
$\quad$ Female & 364 & 2.7 & & & \\
Occupations & & & 0.003 & 3.245 & $1.417-$ \\
& & & & & 7.432 \\
$\quad \begin{array}{l}\text { Farmer or } \\
\quad \text { Fisherman }\end{array}$ & 209 & 6.7 & & & \\
$\quad$ others & 462 & 2.2 & & & \\
Taking anti- & & & 0.66 & 0.833 & $0.369-$ \\
$\quad$ filarial drugs & & & & & 1.882 \\
$\quad$ No & 365 & 3.3 & & & \\
$\quad$ Yes & 306 & 3.9 & & & \\
Total & 671 & 3.6 & & & \\
\hline
\end{tabular}
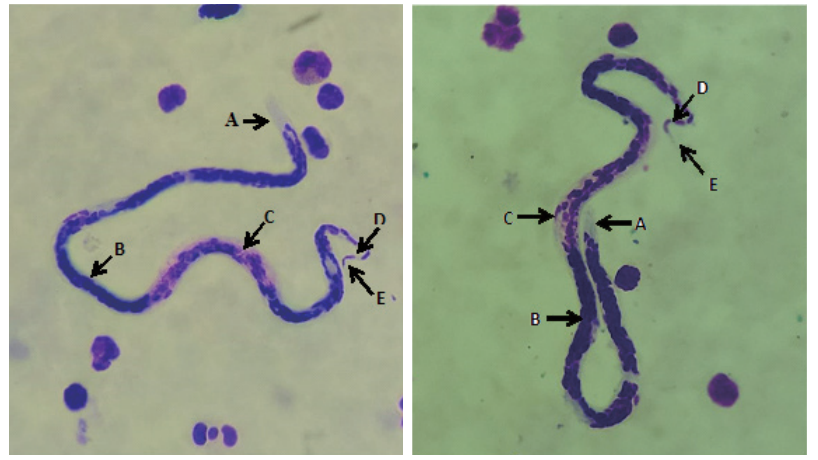

Fig. 2. Microfilariae of Brugia malayi in thick blood smears, Giemsa-stained (pink-stained sheath: it is not visible). (A) The cephalic space has a ratio of width to length of 1:2. (B) microfilaria appeared dark-stained. (C) compact column of the nuclei. (D) wide gap between the terminal and subterminal nuclei. (E) tapered tail (arrows indicate all in photo). 
Table 3. Awareness of respondents on mass drug administration and perception of adverse events

\begin{tabular}{|c|c|c|c|}
\hline \multirow{2}{*}{ Characteristics } & \multicolumn{2}{|c|}{ Awareness (\%) } & \multirow{2}{*}{ Total $(n=526)$} \\
\hline & Lasar $(n=246)$ & Suak Gual (n=280) & \\
\hline \multicolumn{4}{|l|}{ Cause of LF } \\
\hline Worm (parasite) & 1.2 & 3.2 & 2.3 \\
\hline Transmitted by mosquitoes & 16.7 & 27.1 & 22.2 \\
\hline Heredity & 0.4 & 0.0 & 0.2 \\
\hline Does not know & 81.7 & 69.7 & 75.3 \\
\hline \multicolumn{4}{|l|}{ Clinical effect of LF infection* } \\
\hline Lymphoedema in limbs (legs/hands) & 71.5 & 71.4 & 71.5 \\
\hline Fever/body ache & 6.9 & 4.3 & 5.5 \\
\hline Lymphadenitis (swollen arm pit) & 3.7 & 0.0 & 1.7 \\
\hline Swollen breast/scrotum & 2.8 & 0.0 & 1.3 \\
\hline No symptoms & 0.0 & 0.7 & 0.4 \\
\hline \multicolumn{4}{|l|}{ Awareness on MDA } \\
\hline Aware & 74.8 & 71.4 & 73.0 \\
\hline Not aware & 25.2 & 28.6 & 27.0 \\
\hline \multicolumn{4}{|l|}{ Adverse event $(A E)^{*}(n=306)$} \\
\hline Headache & 4.7 & 5.1 & 4.9 \\
\hline Fever & 2.7 & 1.9 & 2.3 \\
\hline Body aches & 0.0 & 1.3 & 0.7 \\
\hline Abdominal pain & 0.7 & 0.6 & 0.7 \\
\hline Dizziness & 4.7 & 3.2 & 3.9 \\
\hline None & 87.2 & 87.9 & 87.5 \\
\hline
\end{tabular}

${ }^{*}$ Response includes single or multiple answers, and the denominator was the total score. Persons with multiple answers, answers were included in the numerator for each answer.

ticipation in MDA programme. As many as 246 and 280 respondents participated in the sociological survey, from Lasar and Suak Gual respectively. The knowledge on the cause of LF causes was low (Table 3), as over $70 \%$ of the respondents were not able to answer. Only $2.3 \%$ of the respondents reported that LF is caused by worms (parasite), and $22.2 \%$ recognized that $\mathrm{LF}$ is a mosquito-borne disease. The gap in the knowledge was significantly $\left(\chi^{2}=9.5 ; P=0.002\right)$ higher in the village in the main island. Most respondents (71.5\%) reported that lymphedema in the arms was the clinical features of LF. Majority of the respondents (73.0\%) were aware of that MDA for LF was conducted in their area and the awareness on MDA was comparable between the study sites (Table 3). However, only $62.4 \%$ of the respondents reported to have participated in MDA in Lasar while it was $57.7 \%$ in Suak Gual. Out of $24 \mathrm{Mf}$ positive cases, 10 (42\%) cases did not participate in MDA. About $13 \%$ of the respondents reported that they experienced adverse events during MDA. Headache, dizziness and fever were reported to be most common adverse events reported by the respondents.

Geographic reconnaissance survey in the study villages showed a number of fresh water ponds, heavily infested with floating aquatic weeds, the host plants of the Mansonia vectors. These ponds serve source of water for domestic requirements such as bathing, washing cloths etc. Swampy areas infested with aquatic weeds is also common in both the coastal villages (Fig. 3). Menfolk engaged in farming and fishing activities reported to be in the working sites till late evening (7.00 PM), exposed at the risk of vector biting.

\section{DISCUSSION}

We detected Brugia malayi infection with more than $1 \% \mathrm{Mf}$ prevalence in both the study villages in Belitung, 10 years after stopping MDA. MDA was stopped in 2010 and the first TAS was conducted in 2012 in this district. Following 3 successful TAS during post MDA surveillance since 2012, this district was declared to have eliminated LF as a public health problem in 2017 [13,14]. Prevalence of Mf above the theoretical transmission breakpoint of $1 \%$ indicated the risk of transmission in both the villages. The results of Mf survey by NIHRD, conducted in 2017 in this district [5] also showed Mf prevalence above the threshold of $1 \%$. This is likely to result in the resurgence of infection in the district in the absence of any organized vector 

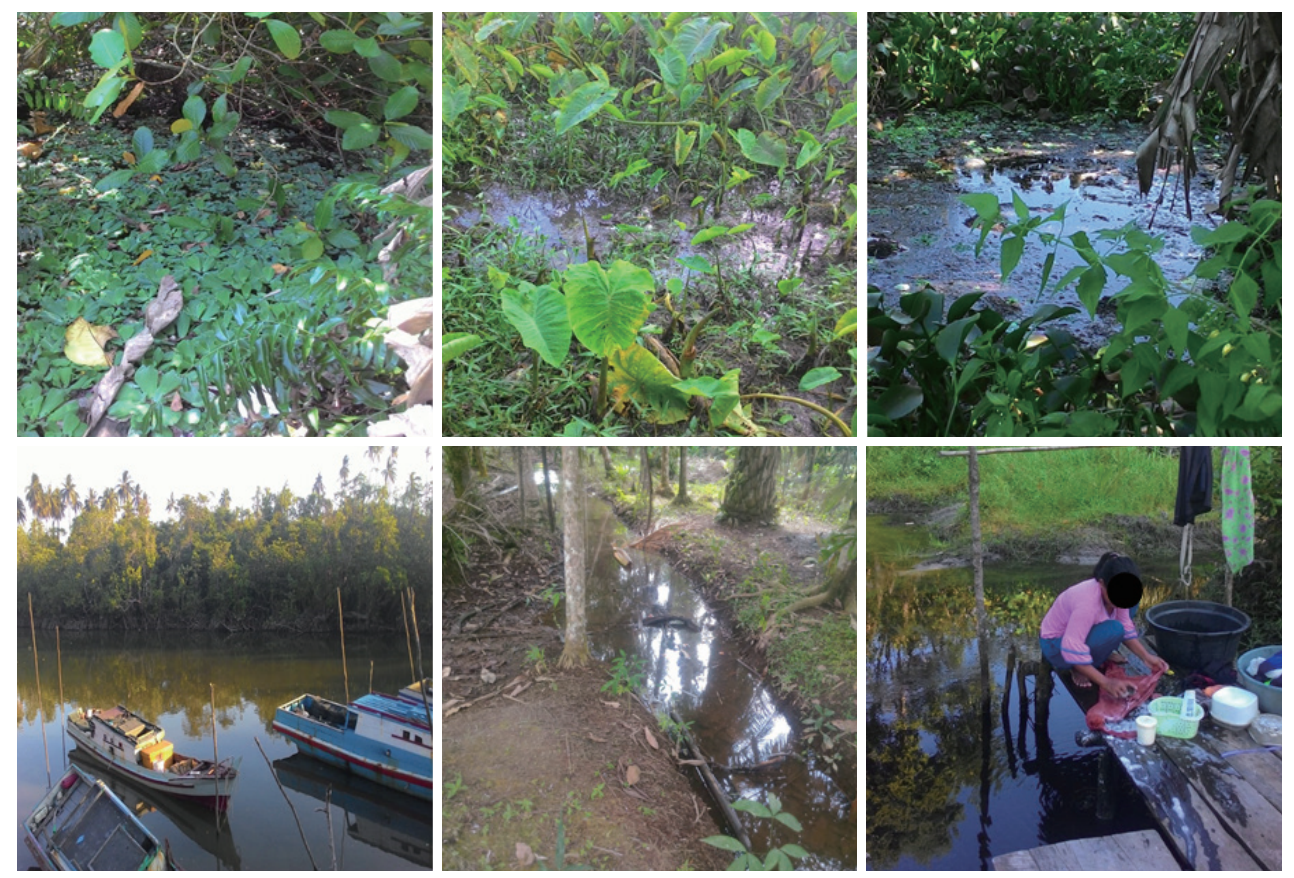

Fig. 3. Mosquito breeding-sites in Lasar and Suak Gual villages.

control programme and formal post-MDA surveillance.

Mf carriers detected in our study, 10 years after last MDA can be considered to be new infections as the life span of the adult worm is known to be $8-10$ years $[15,16]$ and the reproductive life span of 5 years [17]. These Mf positive cases possibly had contracted during post MDA period. The participation of respondents in the MDA was below the recommended coverage of $65 \%$ and only $42 \%$ of Mf positives detected in our study reported to have participated in MDA. With the limitation of long re-call period, the results suggest low compliance. Infection among the non-participating endemic community and infections were expected to have natural loss of infection during the 10 years of post-MDA period. Therefore, the new infections are likely to have contracted after stopping MDA. Assuming the pre-TAS results were from quality assured surveys, Mf prevalence was below $1 \%$ in all the sentinel and spot-check sites indicating lack of evidence for the persistence of infection above threshold levels. However, Mf survey conducted in 2008 as a part of programme evaluation in sentinel and spot-check sites showed Mf prevalence of 3.1 and 3.9\% in 2 sentinel sites. This survey was conducted 2 years before stopping MDA. Suak Gual, one of our study sites was a spot check site during that survey and no Mf positive was reported (personal communication, District Health Office). Therefore, it appears that the Mf positive cases detected in the present survey are fresh infec- tions.

Long-tailed macaques (Macaca fascicularis) is prevalent in this district and detection of Brugia spp DNA in this monkey [5] indicates possible role of zoonotic transmission. As there was no reported movement of Mf carriers to other endemic areas, these infections can be considered indigenous.

The mean Mf density of positive cases was also high, ranging from 120 to 354 per $60 \mu \mathrm{l}$ in the study villages which is higher than the threshold for transmission. Transmission of Wuchereria from low density carriers with less than $10 \mathrm{mf} / \mu \mathrm{l}$ of peripheral blood which is considered as a value that approximates the threshold level of microfilaraemia detectable with conventional diagnostic techniques have been reported [18].

The diagnostic tool used in TAS in this Brugia endemic district was The Brugia Rapid ${ }^{\mathrm{TM}}$ test (BRT) which uses a recombinant $B$. malayi antigen $B m R 1$ to detect antibody specific to Brugia malayi and Brugia timori (Reszon Diagnostics International Sdn. Bhd, 47600 Subang Jaya, Selangor, Malaysia). Results of periodical TAS surveys showed antibody prevalence below the threshold of $2 \%$. The final TAS (TAS3) results showed that the incidence of new infection was below the threshold which is considered as the evidence for total interruption of transmission and the programme has declared elimination of LF in this district. On the contrary, our study results showed Mf prevalence above the threshold. Rao et al. [19] 
2017, reported that antibody prevalence was more among adults than school-aged children (ages 10-17) after stopping MDA and signals coming from high focal infection regions are often diluted when assessment units are large in TAS. This discordant result needs to be investigated further by using appropriate surveillance tools such as molecular xenomonitoring. While discussing the possible resurgence of LF in Pacific islands, combination of efficient vectors, highly mobile population, outdoor lifestyle, MDA coverage/palticipation rates and hard to reach remote/isolated populations are reported to be the possible reasons [20]. Since 2017, there was no LF surveillance in our study district. Therefore, supplementary surveillance, such as cross sectional community survey for filarial infection is needed in order to support the elimination of LF in Belitung, including possible risk of zoonotic transmission. Triple drug regimen can be planned, targeting foci with high prevalence of infection as recommended for communities where post-MDA or post-validation surveillance identified infection suggesting local transmission [21].

Suak Gual is located in Mendanau Island with a population distribution of about one kilometer. Lasar is situated in a lowland island surrounded by beaches and secondary forests. The breeding sources of Mansonia spp. such as fresh water ponds and swampy areas are at proximity to the houses $[12,22]$. Feasibility of larval source management strategy can be explored to prevent vector breeding to reduce the risk of transmission. Active health promotion by involving community leaders is needed to improve community behaviors in order to reduce the risk of filariasis transmission [23,24].

Farmers and fishermen perform daily outdoor activities near the breeding site and hence they are at more risk of transmission as higher prevalence of LF reported among the Mbembe people in Nigeria, attributed to their occupational dispositions [25]. Promotion of personal protection measures such as use of repellent may be useful to protect from the bites of vector.

Filarial infection above the threshold level was found 10 years after stopping MDA in small islands and the mainland of Belitung. An appropriate strategy to monitor the situation in this district is required for an early signal for resurgence of infection. If warranted, measures to prevent transmission can be initiated in hotspots.

\section{ACKNOWLEDGMENTS}

The authors would like to thank communities in Suak Gual and Lasar for their participation and, Provincial health office of Kepulauan Bangka Belitung, District health office of Belitung for their cooperation.

\section{CONFLICT OF INTEREST}

The authors declare no conflict of interest related to this study.

\section{REFERENCES}

1. World Health Organization. Global programme to eliminate lymphatic filariasis: progress report, 2018. Weekly epidemiological record 2019; 94: 457-472.

2. Das PK, Shenoy RK. Helminthic Diseases: Filariasis. Second Edi. Int Encyclof Public Health 2017: 552-560. https://doi.org/10.1016/ B978-0-12-803678-5.00203-4

3. Ministry of Health Indonesia. Situation of Filariasis in Indonesia. Jakarta, Indonesia. Ministry of Health, Indonesia. 2019, pp 12.

4. World Health Organization. Indonesia firmly committed to eliminating lymphatic filariasis as a public health problem. 2020 [Internet]; [cited 2020 Sep 25]. Available from: https:// www.who.int/news-room/detail/29-04-2020-indonesia-firmlycommitted-to-eliminating-lymphatic-filariasis-as-a-publichealth-problem.

5. Santoso, Budiyanto A, Yahya, Ambarita LP, Suryaningtyas NH, Permana GWDS, Supranelfy Y, Ni'mah T, Anorital, Marleta R, Hasan A. Evaluation Study of Filariasis Limfatic Elimination Activities. J Med Sci Clin Res 2019; 7: 870-876. https://dx.doi. org/10.18535/jmscr/v7i4.145

6. Statistics Coordinator of Membalong Subdistrict. Membalong Subdistrict in Figures. Tanjungpandan. 2017.

7. Lemeshow S, Hosmer DW Jr, Klar J, Lwanga SK. Adequacy of Sample Size in Health Studies. New York, USA. John Wiley \& Sons Ltd. 1990, pp 1-239.

8. National Institute Health Research and Development. Data Collection Guidelines for Filariasis Elimination Development Study Model. Jakarta, Indonesia. 2018 (Unpublised).

9. Ministry of Health Indonesia. Regulation of The Minister of Heath, Republic Indonesia Number 94 of 2014 about Filariasis Treatment [Internet]; Ministry of Health Indonesia [cited 2020 Nov 27]. Available from: https://draguscn.com/wp-content/uploads/2018/02/pmk-no-94-ttg-penanggulangan-filariasis.pdf (in Bahasa Indonesia).

10. World Health Organization. Monitoring and Epidemiological Assessment of Mass Drug Administration in the Global Programme to Eliminate Lymphatic Filariasis: a Manual for National Elimination Programmes. Geneva. Switzeland. World Health Organization; 2011, pp 1-78.

11. Supriyono S, Tan S, Hadi UK. Behavior of Mansonia and Potency of Reservoir on Transmitting of Filariasis in Gulinggang Village 
Balangan District South Kalimantan Province. ASPIRATOR 2017; 9: 1-10 (in Bahasa Indonesia). https://doi.org/10.22435/aspirator. v9i1.4443.1-10

12. Supriyono, Tan S, Hadi UK. Mosquito diversity and habitat characteristic in Juai subdistrict, Balangan district, South Kalimantan province. ASPIRATOR 2019; 11: 19-28 (in Bahasa Indonesia)

13. Ministry of Health Indonesia. Tahun ini 13 Kabupaten/Kota dapat Sertifikat Eliminasi Filariasis [Internet]. Available from: https://www.kemkes.go.id/article/print/17100900001/tahun-ini13-kabupaten-kota-dapat-sertifikat-eliminasi-filariasis.html (in Bahasa Indonesia).

14. Ministry of Health Indonesia. Data dan Informasi. Profil Kesehatan Indonesia 2018 [Internet]; Jakarta, Indonesia. Available from: https://pusdatin.kemkes.go.id/resources/download/pusdatin/profil-kesehatan-indonesia/Data-dan-Informasi_Profil-Kesehatan-Indonesia-2018.pdf (in Bahasa Indonesia).

15. Stolk WA, Vlas SJ De, Habbema JDF. Advances and challenges in predicting the impact of lymphatic filariasis elimination programmes by mathematical modelling. Filaria J 2006; 5: 5. 10.1186/1475-2883-5-5

16. Subramanian S, Stolk WA, Ramaiah KD, Plaisier AP, Krishnamoorthy K, Van Oortmarssen GJ, Dominic Amalraj D, Habbema JD, Das PK. The dynamics of Wuchereria bancrofti infection: a model-based analysis of longitudinal data from Pondicherry, India. Parasitology 2004; 128: 467-482. https://doi.org/10.1017/S0031182004004822

17. Vanamail P, Ramaiah KD, Pani SP, Das PK, Grenfell BT, Bundy DA. Estimation of the fecund life span of Wuchereria bancrofti in an endemic area. Trans R Soc Trop Med Hyg 1996; 90: 119-121. https://doi.org/10.1016/S0035-9203(96)90106-6

18. McGreevy PB, Kolstrup N, Tao J, McGreevy MM, de TF. Ingestion and development of Wuchereria bancrofti in Culex quinquefasciatus, Anopheles gambiae and Aedes aegypti after feeding on hu- mans with varying densities of microfilariae in Tanzania. Trans $\mathrm{R}$ Soc Trop Med Hyg 1982; 76: 288-296. https://doi.org/10.1016/00359203(82)90170-5

19. Rao RU, Samarasekera SD, Nagodavithana KC, Dassanayaka TDM, Punchihewa MW, Ranasinghe USB, Weil GJ. Reassessment of areas with persistent Lymphatic Filariasis nine years after cessation of mass drug administration in Sri Lanka. PLoS Negl Trop Dis 2017; 11: e0006066. https://doi.org/10.1371/journal.pntd.0006066

20. Lau C, Sheel M, Gass K, Fuimaono S, David M, Won K, Sheridan $\mathrm{S}$, Graves P. Potential strategies for strengthening surveillance of lymphatic filariasis in American Samoa after mass drug administration: targeting older age groups, hotspots, and household members of infected persons. medRxiv 2020: 1-45. https://doi. org/10.1101/2020.04.07.20056549

21. World Health Organization. Guideline: Alternative Mass Drug Administration Regimens to Eliminate Lymphatic Filariasis. Geneva, Switzerland. World Health Organization. 2017, pp 1-50.

22. Ibrahim. The relationship between environmental conditions and community behavior with the incidence of filariasis in the of Muaro Putuih village, Tiku PHC Tanjung Mutiaran Sub-District Agam in 2016. J Med Saintika 2016; 7: 1-4 (in Bahasa Indonesia).

23. Munawwaroh L, Pawenang ET. Evaluasi program Eliminasi filariasis dari aspek perilaku dan Perubahan lingkungan. Unnes J Public Health 2016; 5: 195 (in Bahasa Indonesia). https://doi. org/10.15294/ujph.v5i3.10013

24. Erlan A. Health promotion in the control filariasis. BALABA 2014; 10: 89-96 (in Bahasa Indonesia).

25. Okon OE, Iboh CI, Opara KN. Bancroftian filariasis among the Mbembe people of Cross River state, Nigeria. J Vector Borne Dis 2010; 47: 91-96. 